\title{
Tribunal de Justiça
}

\section{AGRAVO DE PETIÇÃO N* 11.792}

Mandado de Segurança. Denegação por não haver direito liquido e certo a proteger, uma vez que é assegurado ao Departamento da Renda Mercantil o direito de, em qualquer momento, alterar - sistema de recolhimento do impôsto correspondente às vendas ao consumidor.

Relator: Sr. Des. Antônio Marins Peixoto.

Agravante: Zeferino Teixcira.

Agravado: Departamento da Renda Miercantil da Prefeitura do Distrita Federal.

\section{ACÓRDÃO DA $88^{*}$ CÂMARA CÍVEL}

Vistos, relatados e discutidos êsses autos de Agravo de Petição número 11.792, em que é Agravante Zeferino Teixeira é Agravado o Departamento da Renda Mercantil da Prefeitura do Distrito Federal:

Acordam os Juizses da $8 *$ Câmara Civel do Tribunal de Justiça do Distrito Federal, por unanimidade de votos, em negar provimento ao recurso, pagas as custas pelo agravante.

Trata-se de Mandado de Segurança, em que o Agravante pretende o restabelecimento da concessão do certificado que dispensa a expedição de comprovante ao consumidor.

Foi denegado o Mandado de Segurança, por não haver direito liquido e certo do Impetrante, que pretendia eximir-se da obrigação de fornecer notas fisicas comprovantes de sua venda ao consumidor (art. 27 da Decreto $\mathrm{n}^{\circ} 13.883$ de 8-5-58).

O Dr. Procurador Geral, falando nesta Instância opinou pela confirmação da sentença (fls. 34).

Certa está a sentença, que foi confirmada pelos seus próprios fundamentos, uma vez que é assegurado ao Departamento da Renda
Mercantil o direito de, em qualquer momento, alterar a sistema de recolhimento do impôsto corespondente as vendas ao consumidor.

Rio de Janeiro, 3 de julho de 1959. Dr. Miguel Maria de Serpa Lopes, Presidente. - Moacyr Rebello Horta.

Ciente. Rio, 17 de julho de 1959. Maurício Eduardo Rabello.

Registrado em 17 de agôsto de 1958.

\section{AGRAVO DE PETIÇÃO N* 11.831}

Mandado de Segurança - Impôsto de vendas e consignações - Não é legitima a cobrança dêsse tributo sôbre a parcela do impôsto de consumo.

Relator: Dr. Des. João Coelho Branco.

Agravante: Juizo da $3^{*}$ Vara da Fazenda Pública.

2. Agravante: Prefeitura do Distrito Federal.

Agravados: Antônio J. Ferreira e outros.

ACÓRDÃO DA PRIMEIRA CÂMARA CÍVEL

Vistos, relatados e discutidos êstes autos de Agravo de Petição $\mathrm{n}^{\circ}$ 11.831, em que é primeiro agravante o Juízo da $3^{\circ}$ Vara da Fazenda Pública, segunda agravante a Prefeitura do Distrito Federal e são agravados Antônio T. Ferreira, Rôlhas Metálic as (Crown Cork) S. A.; S. A. Cotonificio Gávea e Trevoli S. A. Artefatos de Couros e Plásticos, acordam os Desembargadores da Primeira Câmara Cível do Tribunal de Justiça, por unanimidade, negar procimento aos recursos, para confirmar, como confirmam, a sentença recorrida, pagas as custas como fôr de lei.

Trata-se de mandado det segurança impetrado pelas firmas agravadas contra o ato do Dr. Diretor da Departamento da Renda 
Mercantil da Prefeitura do Distrito Federal, que diterminou se incluisse no valor do impôsto de rendas e consignações a parcela relativa ao impôsto de consumo pago pelo fabricante. A sentença de fls. 28-31 concedeu a segu:ança e dai o recursa necessário do Juizo e o voluntário da Municipalidade. A Procuradoria Geral, no parecer de fls. 39, opinou pela confirmação da sentença.

Sustentam os impetrantes-agravados que, como fabricantes e vendedores de seus produtos, não estão obrigadơs a pagar o impôsto de vendas e consignações sôbre a parcela do impôsto de consumo, destacado nas notas fiscais que emitem para cada venda de seus prodhtos, em virtude de não ser o último, isto é, o impôsto de consumo, demento componente do preço da operação.

Segundo dispõe a Consolidação das Leis do Impôsto de Consumo (Decreto Federal $n^{\circ} 26.149$ de 5 de janeiro de 1949), nos arts. $1^{\circ}, 2^{\circ}, 10,98$ e 99 , êsse tributo federal deve ser recolhido pelo fabricante ou industrial, que o recobra do primeiro comprador ou primeiro consumidor, para o que o incluirá, em parcela separada, na nota fiscal.

Pode essa parcela separada da impôsto de consumo ser considerada parte do valor da venda, para sôbre ela incidir o impôsto de vendas e consignações?

A própria lei municipal respondia negativamente a interrogação, por isso que 0 § $1^{\text {* }}$ da artigo $4^{\circ}$ do Decreto Municipal $n^{\circ} 13.108$ de 23 de dezembro de 1955 , que regulamentou as Leis Municipais ns, 687 e 820 , respectivamente de 20 de dezembro de 1951 e 27 de julho de 1955, estatuia: "Compreende-se como valor total da operação, para efeito de pagamento do impôsto, o preço da venda das mercadorias e tôdas as despesas cobradas pelo vendedor ao comprador, saja na fatura ou fora, ressalvada a hipótese de despesas comprovadamente feitas em nome e por conta do comprador, caso em que năo será devido o impôsto sôbre as mesmas despesas".

Ora, sendo a pagamento do impôsto de consumo pelo fabricante despesa feita em nome e por conta do comprador, evidente que sôbre ela não seria devido o impôsto de vendas.

Alega-se que a Lei $n^{*} 899$ de 29 de novembro de 1957 exclui expressamente do aludido $\S 1^{\circ}$ do artigo $4^{\circ}$ do Decreto número 13.108 a ressalva que nêle se continha.
Mas a vedação da cobrança persiste por motivo mais alto, isto é, em virtude de proibição constitucional. Em verdade, incorporar o impôsto de consumo ao preço dá mercadoria e cobrar o impôsto de vendas e consignações sôbre êsse preço é fazer incidir tributo estadual ou local sôbre tributo federal. O que a Prefeitura pleiteia é, sem dúvida, exigir impôsto sôbre impôsto federal, renda sôbre renda. Ora, é da t:adição do direito constitucional brasileiro o principia de imunidade intergovernamental reciproca, inscrito no art. 31, V, letra "a", da atual Constituição, segundo o qual nenhuma pessoa de direito público interno - UInião, Estados, Distrito Federal e Municipios - ressalvados os casos previstos, poderá exigir impôsto sôbre bens, rendas e serviços da cutra. Como observa Pontes de Miranda: "Uma das cor:scqüências dos arts. 31 e 32 é a inconstitucionalidade do ato (legislativa ou executivo) oue contenha ou importe em infração dus seus ditames proibitivos. Trata-se de três séries de principios cogentes, vedativos. ou pelo menos concedidos em forma negativa, de que resulta o direito público subjetivo de quem quer que seja lesado pelo ato que infrinja qualquer de suas regras" (Comentários à Constituição de 1946, 2* ed.., 1943. vol. II, p. 145).

$\mathrm{Na}$ csteira dessa interpretaçăo, acolhida pela decisão agravada e que है a única que se coaduna com o regime constitucional vigente, já rumaram firmemente o Supremo Tribunal Federal (Rev. Tribunal de Turisprudência, vol. 1, p. 107, vol. 3, pp. 271 e 428, vol. 4, pp. 136 e 194), o Tribunal de Justiça dò S. Paulo (Rev. Dir. Adm.. vol. 46 , pp. 123 e 137), êste Tribunal de Justiça (Apel. Civ. n* 35.056, in D. I., de $1^{\circ}$ de agôsto de 1957, p. 1.916; Apel. Civ. n 48.223 desta Câmara, julgada em 29 de setembro de 1958) e o próprio Conselho de Recursos Fiscais do Distrito Federal (Coleção de Acórdăos, vol. III, p. 233 e volume V, p. 288; D. O. (Seção II de 21 de janeiro de 1917).

Essas as razões por que se impõe a confirmação da decisão agravałà, que concedeu a sŁgurança impetrada.

Rio de Janeiro, 2 de sctembro de 1959. - Guilherme Estelita, Presidente. - Joăo Coelho Branco, Relator. - Elmano Ciuz

Ciente, 17 de setembro de 1959. - Mauricio Eduardo Rabello.

Registrado em 14 de ou ibro de 1.959. 